\title{
Sickle cell disease and maternal mortality in Nigeria
}

\begin{abstract}
Nigerian continues to bear the greatest burden of sickle cell disease in Sub-Saharan Africa. This disease is more critical in pregnancy and many of such pregnancies result in maternal mortality. Importantly, not much research had been conducted in sickle cell disease and maternal mortality in Nigeria. This paper reviewed sickle cell disease and maternal mortality in Nigeria. Literature was sourced from books, pubmed and google search engines. The search terms were sickle cell disease, maternal mortality and Nigeria and relevant published articles were reviewed. The review indicated that the reviewed articles were all hospital based studies. This paper then moved for community and household studies in order to obtain a fuller-clearer picture of the problem. The paper thus brought out the importance of medical sociologists in sickle cell disease research. High maternal mortality and high health complications due to sickle cell disease were also indicated. This paper therefore concludes that sickle cell disease is a push factor in the Nigerian high maternal mortality status.
\end{abstract}

Keywords: sickle cell disease, maternal mortality, prevalence and pregnant women
Volume 3 Issue $3-2018$

\author{
Caroline Okumdi Muoghalu \\ Obafemi Awolowo University, Nigeria
}

Correspondence: Caroline Okumdi Muoghalu, Medical Sociologist, Department of Sociology and Anthropology, Obafemi Awolowo University, Ile Ife, Nigeria, Tel +234805668I600, Email omuoghal@yahoo.co.uk

Received: January II, 2018 | Published: June 22, 2018

\section{Introduction}

Sickle cell is a genetic disease of the hemoglobin chain of the red blood cells. ${ }^{1}$ This genetic disorder is usually inherited from one's parents. ${ }^{2}$ As noted by World Health Organization, ${ }^{3}$ sickle cell anaemia is a common genetic condition due to a haemoglobin disorderinheritance of mutant haemoglobin genes from both parents. Such haemoglobinopathies - thalassaemias and sickle cell anaemia are globally widespread and the public health implications are significant. ${ }^{3}$ Sickle cell disease can be in several forms which include sickle cell anaemia (when inherited in homozygous state), sickle cell beta plus thalassemia, sickle beta zero thalassemia and others. ${ }^{4}$ Sickle cell Anaemia is a disease in which the body produces abnormally/sickle shaped blood cells which do not last as long as normal round red blood cells thereby resulting in dizziness, pains and organ damage. ${ }^{5}$ Sickle cell disease is a common genetic blood disorder that afflict mainly Africans, Brazilians, the Caribbean and Asians. ${ }^{6}$ In Africa,${ }^{1}$ described it as a silent killer and one of the supreme public health issues of this era. Nigeria bears a heavy burden of the disease with 20 to 30 percent prevalence. ${ }^{7,4}$ In fact, Alhasan (2014) noted that forty million people were carrying the gene for sickle cell disease in Nigeria. The World Health Organization ${ }^{7}$ also noted that the disease affects 2 percent of Nigerians making it a great public health problem in the country. Owing to the fact that sickle cell is a blood disorder, it is likely to have devastating effects during pregnancy and childbirth. In the same vein, ${ }^{8}$ noted that pregnancy in sickle cell disease patients is linked with increased risk to both mother and fetus. The incessant maternal deaths among pregnant women living with sickle cell disease had been reported by many scholars, ${ }^{9}$ Ocheni, ${ }^{10}$ Ogedengbe \& Akinyanju, ${ }^{11,8}$ These deaths happen frequently in different parts of the countries as attested to by these studies. As such, this mini review becomes significant as it would bring to limelight this enormous public health problem and which may engender effective intervention programme towards reducing maternal mortality among pregnant women living with sickle cell disease.

The issue of sickle cell and maternal mortality is especially important because in Nigerian, every woman wants to bear as many children as possible. This is in the face of poor utilization of maternal healthcare in Nigeria. ${ }^{12}$ Onwudiegwu ${ }^{12}$ further observed that pregnant women attended antenatal care in the early 1980s than in year 2000 which points to issues in the political economy of Nigeria. In the same vein, Ezieke \& Muoghalu ${ }^{13}$ submitted that there are socio-cultural factors that debar women from utilizing maternal health care services. This becomes a more serious problem if the woman is living with sickle cell disease. These socio-cultural factors cannot be separated from political economy of Nigeria in which there has not been any concrete policy implementation on people living with sickle cell disease in-spite of the fact that sickle cell disease is a public health concern in Nigeria. Political economy therefore becomes a relevant framework on which to situate this paper. Political economy is a science of the statesman, to supply plentiful revenue for the people and to enable them provide such a revenue for subsistence for themselves and supply the state or common wealth with a revenue sufficient for public services. ${ }^{14}$ The lack of political will on the part of Nigerian government may be partly the reason for incessant maternal death among women with sickle cell disease in the country. This review papers set out to ascertain the prevalence of maternal mortality among women living with sickle cell disease in Nigeria.

\section{Methods}

Materials were sourced from published peer reviewed research articles from books, pubmed and google search engines. The terms used in the search were sickle cell disease, maternal mortality, prevalence and Nigeria. Owing to the fact that researchers in Nigeria had not paid much attention to the problem of sickle cell and maternal mortality, relevant literature were difficult to find and four relevant articles were reviewed for this paper.

\section{Sickle cell disease and maternal mortality in Nigeria}

Maternal mortality is the concept used to describe the number of women that died in pregnancy or during or few weeks after child birth. Maternal mortality rate is a health indicator measured by the number of maternal deaths divided by total births times 1000.15 In 
this mini review, Ugboma \& George ${ }^{8}$ measured maternal mortality by simple percentages of sickle cell disease pregnant women that died during child birth within the study period. Omole Ohonsi et al., ${ }^{16}$ and Ogedengbe \& Akinyanju ${ }^{11}$ measured maternal mortality by number of maternal deaths per 1000 deliveries. Importantly, the reviewed studies were all conducted in teaching hospitals. Teaching hospital is the highest/tertiary level of healthcare where the best medical care can be obtained in Nigeria. The three teaching hospitals in the reviewed studies were well spread across Nigeria which represents a balanced view of the problem in Nigeria. Ocheni, ${ }^{10}$ studied pregnant women with sickle cell disease attending clinic in the University of Nigeria Teaching Hospital, Enugu, South East Nigeria. Ogedengbe \& Adeyanju ${ }^{11}$ studied pregnant women with sickle cell disease attending antenatal clinic in Lagos University Teaching hospital in South West Nigeria. Omole Ohonsi et al., ${ }^{16}$ conducted their study in Aminu Kano Teaching hospital, Kano in Northern Nigeria and Ugboma \& George ${ }^{8}$ did their own study in University of Port Harcourt Teaching Hospital in South -South Nigeria. As such, all the studies reviewed were hospital based. The study subjects were pregnant women with sickle cell disease who attended antenatal clinics in these hospitals.

Sickle cell disease continues to be a strong factor in maternal mortality. This is especially so considering the poor healthcare system of Nigeria. As noted by Ogedengbe \& Akinyanju ${ }^{11}$ pregnancy aggravates the medical complications of sickle cell disease and the disease complicates pregnancy leading to high rate of perinatal and maternal mortality. The high rate of health complications was also reported by Omole Ohonsi ${ }^{16}$ \& Ogedengbe \& Akinyaju. ${ }^{11}$ Furthermore, Ocheni et al., ${ }^{10}$ had similar findings and conclusions in South East Nigeria. With these health complications in pregnancy, it is obvious that pregnant women living with sickle cell disease experience pregnancy as highly precarious and with much discomfort, fear and high level of uncertainty. It was therefore not surprising that these studies also found high maternal mortality. Indeed, Ogedengbe \& Akinyanju, ${ }^{11}$ found perinatal mortality rate of 233 and 111 per 1000 deliveries in HBSS and HBSC respectively. The study also found maternal mortality rates of 129 and 111 per 1000 deliveries in HBSS and HBSC patients respectively. In the same vein, Ugboma \& George $^{8}$ found that 20 percent of women in their study had induction of labour, 60 percent were delivered by emergency section, 44 percent of women delivered before 37 completed weeks and 20 percent of the women died. Furthermore, Omole Ohonsi et al., ${ }^{16}$ reported 26 maternal deaths per 1000 deliveries and Afolabi et al., ${ }^{17}$ also found in Lagos that there were more perinatal and maternal deaths in HBSS women compared with HBAA. This scenario showed that across Nigeria, pregnancy almost means a death trap for women with sickle cell disease. Importantly, this is not only in Nigeria. In a recent review of sickle cell and maternal mortality in Africa, Yadufashije et al., ${ }^{1}$ also submitted that sickle cell disease is a silent killer which had been ignored in most African countries. They concluded that in almost every African country, there was very high risk of maternal fetal complications including deaths and premature deliveries. Owing to the fact that sickle cell disease comes with a lot of symptoms, it makes life uncomfortable for pregnant women living with it. As such, many pregnant women living with sickle cell disease may die before the end of the pregnancy which makes sickle cell dangerous with so much complications in pregnancy.

Generally, the reviewed studies found high rate of complications among pregnant women with sickle cell disease. These bleak findings also informed the conclusions drawn by the studies. For instance, Ugboma \& George ${ }^{8}$ concluded that there was high maternal mortality among women with sickle cell disease. Also, Omole Ohonsi et al., ${ }^{16}$ concluded that pregnant women with sickle cell disease who had preconceptual care in addition to prenatal care had fewer pregnancy complications than those who had only prenatal care. These submissions continue to re-enforce the fact that pregnancy and childbirth is riskier for women with sickle cell disease than other women. Importantly, the effect of preconceptual care which resulted in fewer complications among pregnant women with sickle cell disease is worthy of note. It suggests that preconceptual care may be an effective strategy. However, it is not clear how many women with sickle cell disease will have access to preconceptual care in the next twenty years in Nigeria due to lack of awareness, facilities and political will.

\section{Brief Discussion}

This mini review indicated high rate of health complications and maternal mortality among pregnant women with sickle cell disease in the study areas/Nigeria. This showed that sickle cell disease is deadly in pregnancy because the hospitals where these studies were conducted are the best in Nigeria and if such high health complications and mortality were recorded in the highly skilled specialized settings, it means that the maternal mortality among women in the general population (some of whom may never attend antenatal care or who may never have access to a teaching hospital or who patronize traditional birth attendants) is likely to much higher.

Importantly, this problem resides in the political economy of Nigeria. There is no political will on the part of Nigerian leaders to tackle the problems associated with sickle cell disease in the country in-spite of the fact that it afflicts so many people. In June $2016,{ }^{18}$ the National house of Assembly legislated that cost of treatment for sickle cell disease patients should be subsidized, but this has not become a reality. Also, in the political economy resides the fact that many pregnant women do not have access or cannot afford even secondary level health care facilities, let alone attending the Teaching hospitals. Apart from these, socio-cultural and economic/demographic factors may play strong roles in the utilization of these health facilities by pregnant women with sickle cell disease.

The implication of these studies is that pregnancy is a very risky event for women with sickle cell disease in Nigeria no matter the level of healthcare available to pregnant women. In-fact, one can say that pregnancy cannot be for women with sickle cell disease in Nigeria. This assertion is highly problematic considering the fact that, in the sociology of Nigerians as a people, every woman wants to have children of her own and it is what the society expects of her. In-fact, if a woman does not have children, she is treated with scorn no mater her level of achievements in other areas. This is why every Nigerian woman aspires to have children irrespective of whether it endangers her life or not. The implication of the study for health practitioners is to intensify efforts and strengthen comprehensive and intensive care for women with sickle cell disease in Nigeria. In drawing Implications for further studies, all of these reviewed studies were conducted in hospital settings and studies have not explored the lived experiences of pregnant women with sickle cell disease in Nigeria. a study focusing on lived experiences will expose the sufferers side of the story. This I believe would give a fuller picture of the problem of sickle cell and maternal mortality. This points to the importance of medical sociologists in containing this great public health concern 
in Nigeria. As such, I quite agree with Omole-Ohonsi et al (2012), that multicentre studies will be required to obtain the bigger picture. Indeed, community and household studies which I believe will generate higher maternal mortality rates would create a fuller/clearer knowledge of the problem. Also, further studies should examine the association between maternal mortality among women with sickle cell disease and socio-cultural, economic/demographic factors in Nigeria.

\section{Conclusion}

The reviewed studies had established the fact that pregnancy among women with sickle cell disease is associated with high maternal mortality and high health complications. This paper therefore concludes that sickle cell disease is a push factor in the Nigerian high maternal mortality status. The paper recommends that health authorities should target reduction in sickle cell maternal mortality by introducing free health care for pregnant women with sickle cell disease. Also, preconceptual care should be expanded by health authorities and its awareness should be created among the general population. I strongly believe that these strategies constitute the right step towards the containment of this public health problem.

\section{Acknowledgements}

None.

\section{Conflict of interest}

The author declares there is no conflict of interest.

\section{References}

1. Yadufashije C, Sangano G, Samuel R. Prevalence of Sickle cell disease in Pregnant Women and neonates in Africa. International Journal of Interdisciplinary Innovative Research \& Development. 2017;2(1):1-5.

2. Muoghalu CO. The health workers perspectives in the management of sickle cell disease in an Urban health centre in Ile-Ife, Nigeria. Journal of Hematology \& Thromboembolic Diseases.

3. World Health Organization Secretariat report. Fifty-ninth world health assembly, provisional agenda item. 2006:1-5.
4. Adewoyin AS. Management of Sickle cell disease: A Review for physician education in Nigeria (Sub-Saharan Africa). Anemia. 2015.

5. Sickle cell anaemia. United States National Library of Medicine. 2017.

6. Dyson S, Atkin K. Genetics and Global Public Health: Sickle cell and Thalassaemia. 1st ed. London; 2012.

7. World health organization. Sickle disease prevention and control. Nigeria: WHO Country Office; 2014.

8. Ugboma H, George I. Sickle cell disease in pregnancy: maternal and fetal outcome in Port Harcourt, Nigeria. British Journal of Medicine and Medical Research. 2015;7(1):40-44.

9. Alhassan K. Nigeria ranks first in sickle cell disease burden worldwide with $40 \mathrm{~m}$ cases, Leadership Newspaper, 2014.

10. Ocheni S, Onah H, Ibegbulam O, et al. Pregnancy outcomes in patients with sickle cell disease in Enugu, Nigeria. Niger J Med. 2017;16(3):227230 .

11. Ogedengbe O, Akinyanju O. The Pattern of Sickle cell disease inpregnancy in Lagos, Nigeria. West Afr J Med. 1993;12(2):96-100.

12. Onwudiegwu, Uche. The Influence of Poverty on the Utilization of Maternal Health Services in Nigeria in Research and Policy Directions on Poverty in Nigeria. $77-85$.

13. Ezieke, B, Muoghalu C. Socio-cultural factors in the utilization of maternal health services among pregnant women in Ado-Ekiti, Nigeria. Unpublished MSc Thesis, 2016.

14. Smith A. An enquiry into the nature and causes of the wealth of nations. 1776.

15. Scott J, Marshall J. Oxford Dictionary of Sociology. United Kingdom, Oxford University Press. 2005.

16. Omole Ohonsi A, Ashimi O, Aiyedun T. Preconception care and sickle cell anaemia in pregnancy. Journal of Basic \& Clinical Reproductive Science. 2012;1(1-2):12-18.

17. Afolabi B, Iwuala N, Iwuala I, et al. Morbidity and Mortality in Sickle cell pregnancies in Lagos, Nigeria:: A case control study. J Obstet Gynaecol. 2009;29(2):104-106.

18. News Agency of Nigeria (NAN), In Nigeria Reps want FG to subsidise Sickle Cell patients' treatment cost. 2016. 